\title{
Work Conditions and TASKs of SCHOOL COUNSEllor
}

\begin{abstract}
The main aim of the research was to become acquainted with the conditions of work and the tasks of the school counsellor resulting from the psychological and pedagogical help performed at educational facilities. The following two methods were used to obtain the research material: the diagnostic survey and assessment. The results of quantitative analyses were classified into the following areas: the conditions of work, the school counsellor's duties, the forms of pedagogical help in their work with the students, parents and teachers, the factors that influence the school counsellor's model of work and individual features important in the profession of school counsellor. The mentioned analyses indicate that the contemporary counsellor is mainly a woman (the profession is feminised), with higher education, systematically improving and supplementing their knowledge so as to perform the tasks set by the pedagogical supervision and family, school and local environment. Thanks to adequate professional preparation and application of a wide range of forms of help for the students, teacher and parents, the school counsellor constitutes a significant link of psychological and pedagogical help performed at the educational facilities.
\end{abstract}

KEYWORDS: school counsellor, diagnostic testing verification, working conditions, counsellor's tasks, forms of psychological and pedagogical help

\section{INTRODUCTION}

The beginnings of the profession of school counsellor date back to the school year 1973/1974. Then the Ministry of Education authorized the curators of school districts to implement the position of the counsellor who was to "organize and 
coordinate the school activities in the scope of pedagogical care and help for children and to increase the level of parents' pedagogical culture" in the form of an experiment in several urban schools counting over 600 students (the Regulation of the Ministry of Education on Organization of Education in the School Year 1973/1974). This short provision included in the instruction that constitutes an appendix to the Regulation of the Minister of Education of $1^{\text {st }}$ February 1973 on Organization of Education in the School Year 1973/1974 became the basis for establishing the position of the school counsellor. The establishment of the new position was a part of the broadly understood tradition of psychological and pedagogical help in Poland (Lewandowska-Kidoń, Kalinowska-Witek, 2016, pp. 13-14). One should notice that the instruction implementing the position of the school counsellor did not specify his/her duties, but only indicated the directions of the following actions: organization and coordination of school activities in the scope of pedagogical care and help for children; increasing the level of parents' pedagogical culture (Dąbek, 1988, pp. 6-8).

The Regulation on the School Counsellor issued in 1975 formally introduced the profession of school counsellor, defined the required education background, higher master's degree in the field of pedagogy or another branch of studies with the condition of having three-year professional experience at school or another educational facility (Lewandowska-Kidoń, KalinowskaWitek, 2016, p. 14). In this period the teachers with experience and first of all with good results at pedagogical work took the position of the school counsellor (Jundził, 1993, p. 533).

It was assumed from the beginning that the school practice and experience of first employed counsellors would be the basis for formulation of the scope of their actions and duties (Szczurkowska, Mazur, 2013). Obviously, similarly as at present, some headmasters were using the counsellors for actions connected with daily needs of the school, such as: substituting absent teachers, auxiliary or administrative works, participation in trainings. Such a situation, which has not changed to this day, gave many teachers an excuse to feel released of the duty to work with students that cause educational problems or have school difficulties as well as with their parents. The legal acts passed in the following years (the Regulation of the Ministry of Education of $1982,1993,2003,2010,2013,2017)$ were to precisely define the tasks of 
the school counsellor, but due to their complexity, they failed to meet the assumed target. After the educational system reform of 1999, the position of the counsellor was provided for each level of education (i.e. in primary school, lower secondary schools and upper secondary schools). However, in practice, it frequently happened that the established positions of the counsellors were not created at all or the already existing positions of the counsellors were liquidated, such decisions being justified by the tasks of the so-called "new" class teacher, who was to take over their functions (Dudzikowa, 1999, p. 11).

Currently the mode of school counsellor's work and the scope of his/her duties is settled by the Regulation of the Ministry of Education of $9^{\text {th }}$ August 2017 on Organization and Granting Psychological and Pedagogical Help in Public Kindergartens, Schools and Facilities (Dz.U.2017.1591 [Journal of Laws of 2017, item 1591]).

However, there still is a discussion pending at the level of the Ministry of Education, local authorities and educational centres regarding the tasks of the counsellor in the organization of psychological and pedagogical help in the mentioned centres, his/her role and position at school, work time, qualifications, required competencies and their structure.

Already in the first years when the profession of school counsellor was established, researchers were interested in various areas of his/her work. The research performed so far can be classified as follows:

- the research of Wanda Barbara Dąbek carried out in the area of southern Poland in the years 1978-1982, regarding the factors that influence the performance of school counsellor's professional tasks. It involved 156 counsellors, 154 headmasters, 360 teachers, 2335 students and 853 parents (Dąbek 1988, p. 22-96);

- the research of Jolanta Bajurska carried out in 1995 in the area of Cracow, Warsaw, rural areas of these regions, among 185 students of upper primary school classes, 101 parents and 82 teachers. The aim of the research was to assess the counsellor's activity by the students, teachers and parents (Bajurska, 1995, p. 22-25);

- the research of Grażyna Gajewska carried out in 2001 among 316 students; among others, it showed that $34 \%$ of the respondents were unfamiliar with the person of the counsellor (Gajewska, 2001, p. 32-39); 
- the research of Bożena Matyjas carried out in the years 1988-2002 regarding the participation of school counsellor in the work of the educational care facility; it involved 147 students, 19 teachers, 6 counsellors and 6 headmasters (Matyjas, 2002, p. 45-48);

- the research of Hanna Śniatała carried out in 2010 among 63 students of upper primary school classes. Its objective was to define the students' expectations from the school counsellor (Śniatała, 2010, pp. 33-36);

- the research of Robert Bielecki carried out in 2012 among 80 upper secondary school students; it was to examine the attitude of the students towards the school counsellor and to define his/her activities that they believed to be the most important (Bielecki, 2012, p. 21-28);

- the research of Teresa Lewandowska-Kidoń carried out in 2015 among 97 candidates for teachers, which was to assess the reasonability of the counsellors' employment at schools and to find out how the tasks they perform are perceived (Lewandowska-Kidoń, 2015, p. 50);

- the research of Teresa Lewandowska-Kidoń and Barbara KalinowskaWitek of 2015 regarding the image of school counsellor among $1216^{\text {th }}$ graders in primary school and 219 students of lower secondary school, their parents and teachers. The research was carried out in the Warsaw and Lublin voivodships (Lewandowska-Kidoń, 2015, pp. 50-58);

- the research of Joanna Wierzejska on the relationship between the school counsellors' sense of subjectivity and their personality work determinants carried out in 2017 in the Lublin, Podlaskie and Mazovian voivodships (Wierzejska, 2018).

The results of the existing research allow to determine that in the students, teachers' and parents' opinion the counsellor is a desirable person at school; s/ he is a mediator in the teacher-student and parent-student relationships; some students whose school or family situation is sometimes difficult use his/her help (approx. 1/3 of all students); s/he must be gifted with particular personal features, among which the following occur frequently: trustworthiness, objectivity, empathy, cordiality, openness, helpfulness, patience; s/he must also be a good listener and enjoying respect of others. In the school environment, it 
is indispensable to create mechanisms that release motivation, ingenuity and initiative of school counsellors and to enable them to participate in trainings in the scope of coping with stress and own emotions as well as emotions of persons they are to assist. Due to changing conditions of counsellor's work, the existing research results must be verified and updated. This was the assumed aim when undertaking the research of the conditions of school counsellor's work.

\section{THE METHODOLOGICAL ASSUMPTIONS OF THE PRESENT RESEARCH}

The subject of the research was the profession of school counsellor as well as its legal, environmental and individual conditions. It was assumed that the profession is a public trust position, which places the counsellor in the overall structure of conditions comprising:

- the legal and administrative levels (such as the directions of the state educational policy, the guidelines of the educational law, the promoted norms and values);

- the environmental level (the environment of the educational institution, where s/he works, the local environment, the students' family environment);

- the individual level (knowledge, skills, individual features) (Kwiatkowska, 2008, pp. 167-168).

The main aim of the research was to become acquainted with the conditions of work and the tasks of school counsellor within the framework of the psychological and pedagogical help organized at educational facilities. Taking into consideration the aim of the research, the diagnostic and verification procedures were decided to be the most suitable.

The aim of the diagnostic layer was to define the scope of school counsellor's tasks and to detect the determinants that influence his/her model of work. The questions asked regarded experience as well as observation connected with experience. Dictionaries define experience as "a conscious activity of obtaining information about a subject by its personal approach." Whereas observation is treated as "careful tracing of a certain phenomenon." The result of such actions is a broad empirical field that constitutes a data source. 
The aim of the verification layer was to determine whether there is a dependency between some particular factors and the assumed model of school counsellor's work. The verification answered the question of what factors mainly determine the performed model of counsellor's work within the framework of psychological and pedagogical help.

The main objective of the study was specified in detail and comprised by the following questions:

- What factors condition the counsellor's work? The factors taken into consideration were: independent of counsellor (such as: work experience, degree of professional promotion, location of school, type of school, assignment of tasks and duties, provisions of the educational law), partially dependant (such as: local environment; school environment; school customers - parents and students; the counsellor's competencies - personal features and attitudes, knowledge, skills and area of such competencies) and dependant (such as: identification with the profession, professional aspirations, performed tasks, the applied forms of work).

- Does the scope of tasks assigned to school counsellor differ and to what extent due to: work environment (urban, rural, local, family, school), the type of establishment (primary school, secondary schools of different types), the objectives and tasks of the given school as well as the organization of psychological and pedagogical help in it?

- What practical tasks and forms of work does the counsellor perform according to the persons surveyed?

- What type of professional personality do the questioned counsellors represent?

\section{Research methods}

Taking into account the subject and the aim of research, two research methods were applied.

- The diagnostic survey method. Within the framework of the survey, the following research methods were applied: the questionnaire "My Daily Professional Duties" developed by the authoress, the Interpersonal Competence Questionnaire (ICQ) by D. Buhrmester, W. Furman, M.T. Wittenberg and H.T. Reis (2017) and the Composite Indicator of 
Systemic Stress (CISS) by N.S. Endler and J.D.A. Parker (Szczepaniak, Strelau, Wiśniewski, 1998);

- The assessment method. The research used two adjective scales developed by the authoress, i.e. the scale "My Professional Preferences" and the scale "The Areas of Pedagogical Competencies".

The research target population was the professional group of school counsellors employed in different types of schools, which can be defined as follows:

- the subject: school counsellors;

- sample unit: selected primary schools, lower secondary schools or primary schools with lower secondary school divisions, special schools, complexes of schools, upper secondary schools, technical upper secondary schools and $1^{\text {st }}$ degree branch schools;

- spatial range: the Silesian, Opole and Lesser Poland voivodships;

- time and place of research: year 2018 (Matuszak, 2011, pp. 33-39).

\section{Organization of research}

The preparatory stage for the research began in June 2017. At the first stage of performance of the research project the problem situation was defined, the variables and determinants were distinguished. The results of observations and conversations with the school counsellors as well as personal experience in the performance of the profession decided among others about the idea of the work. The correctness of the basic versions of questionnaires and measuring scales was verified in the pilot research carried out on the sample of 57 counsellors.

The main research was carried out in the period between March and June 2018 in the area of the Silesian, Opole and Lesser-Poland voivodships. The total of 212 counsellors employed in primary schools (including those with lower secondary school classes), basic and technical upper secondary schools of general and vocational education, complexes of schools and special schools. The selection of the sample was deliberately random. The basic criterion for the selection of the sample was for the subjects to have pedagogical qualifications and to be employed as a school counsellor. The 
sample was selected based on the lists of schools given in the Educational Information System and the websites of the Voivodship Offices of Education. A total of 1,200 schools were randomly selected. In practice, this selection was incidental. Possibility of conducting research depended on the school head's consent and the willingness of the school counsellors to take part in the research.

The obtained empirical material was subject to the statistical analysis and interpreted quantitatively and qualitatively.

\section{THE ANALYSIS AND INTERPRETATION OF THE RESEARCH RESULTS}

The research covered 212 school counsellors. As shown in Table 1, the surveyed group was dominated by women (93.4\%). It is clearly seen that the position is feminised. Men constituted only $6.6 \%$ of the surveyed persons.

Table 1

Gender of the surveyed school counsellors

\begin{tabular}{|c|c|c|}
\hline Sex & Incidence & $\%$ \\
\hline women & 198 & 93.4 \\
\hline men & 14 & 6.6 \\
\hline total & 212 & 100 \\
\hline
\end{tabular}

Source: authoress.

The surveyed school counsellors were quite differentiated as to their age (Table 2). The largest group were people aged 36-40 (20.8\%). Then the two similar age groups were people aged 51-55 (19.8) and 41-45 (18.4\%). The smallest group in number were counsellors aged 25-30 (2.8\%) and 61-65 $(2.3 \%)$. 
Table 2

Age of the surveyed school counsellors

\begin{tabular}{|c|c|c|}
\hline Age & Incidence & \% \\
\hline $25-30$ & 6 & 2.8 \\
\hline $31-35$ & 23 & 10.9 \\
\hline $36-40$ & 44 & 20.8 \\
\hline $41-45$ & 39 & 18.4 \\
\hline $46-50$ & 32 & 15.1 \\
\hline $51-55$ & 42 & 19.8 \\
\hline $56-60$ & 21 & 9.9 \\
\hline $61-65$ & 5 & 2.3 \\
\hline total & 212 & 100.0 \\
\hline
\end{tabular}

Source: authoress.

The statistical age analysis of the surveyed counsellors allows to state that the most numerous group among the surveyed persons were the counsellors between the age of 39 and 52. The minimum age of the counsellors was 26, whereas the maximum -64 . The median shows the average value is the age of 44 among the surveyed counsellors.

The work seniority of the surveyed school counsellors was also various, which is depicted in Table 3.

Table 3

Work seniority of the surveyed school counsellors

\begin{tabular}{|c|c|c|}
\hline Employment duration & Incidence & \% \\
\hline up to one year & 10 & 4.7 \\
\hline $1-5$ years & 25 & 11.8 \\
\hline 6-10 years & 28 & 13.2 \\
\hline $11-15$ years & 42 & 19.8 \\
\hline $15-20$ years & 28 & 13.2 \\
\hline $21-25$ years & 28 & 13.2 \\
\hline more than 25 years & 51 & 24.1 \\
\hline total & 212 & 100 \\
\hline
\end{tabular}

Source: authoress. 
As shown in Table 3, the largest number of the surveyed counsellors (24.1\%) works within the time range of over 25 years. The next range $(19.8 \%)$ is 11-15 years. At the same level (13.2\%), there is the number of the surveyed counsellors of work seniority 6-10, 16-20 and 20-25 years. The fewest (4.7\%) of the surveyed counsellors constituted those working up to one year, a little more from 1 to 5 years $(11.8 \%)$.

As Table 4 depicts, the majority of the examined counsellors received the degree of certified teacher $(64.6 \%)$ or the appointed teacher $(27.1 \%)$, the smallest number were the contract counsellors (10.4\%) and the trainees $(3.3 \%)$.

Table 4

Division of the surveyed counsellors due to the degree of professional promotion

\begin{tabular}{|c|c|c|}
\hline $\begin{array}{c}\text { Degree of professional } \\
\text { promotion }\end{array}$ & Incidence & $\%$ \\
\hline trainee & 7 & 3.3 \\
\hline contract teacher & 22 & 10.4 \\
\hline appointed teacher & 46 & 27.1 \\
\hline certified teacher & 137 & 64.6 \\
\hline total & 212 & 100 \\
\hline
\end{tabular}

Source: authoress.

All of the surveyed counsellors had higher master's degree with pedagogical preparation and completed post-graduate studies, supplementary courses and workshops. The dominating post-graduate studies branches that they completed were:

- oligophrenic pedagogy, tyflopedagogy, surdopedagogy (62.3\%),

- sociotherapy (53.7\%),

- pedagogical therapy (37.4\%),

- logopaedics (17.6\%).

Some of the examined persons completed more than one qualification branch. 
Among the supplementary forms of training completed by the counsellors the most frequent are:

- diagnosis and therapy of addictions (97.8\%),

- prevention of aggression and violence $(68.2 \%)$,

- interpersonal communication (23.5\%),

- mediation (13.4\%).

Most of the surveyed persons finished more than one form of professional training.

The surveyed counsellors work in schools of different types and different size with various numbers of students. The largest number of the surveyed counsellors works in primary schools or primary schools with lower secondary school classes. The other types of schools are upper secondary schools: $1^{\text {st }}$ degree branch, technical, general education, complexes of schools and a special school. All of the surveyed counsellors work in schools situated in cities with the population of over 100,000 or towns with the population of less than 100,000 .

Table 5

Division of the counsellors due to the number of students at school where they are employed

\begin{tabular}{|c|c|c|c|}
\hline Number of students & Incidence & \% & Rank \\
\hline up to 100 & 14 & 6.6 & 6 \\
\hline $101-200$ & 58 & 27.4 & 1 \\
\hline $201-300$ & 34 & 16.0 & 4 \\
\hline $301-400$ & 38 & 17.9 & 5 \\
\hline $401-500$ & 26 & 12.3 & 2 \\
\hline over 500 & 42 & 19.8 & - \\
\hline total & 212 & 100 & 3 \\
\hline
\end{tabular}

Source: authoress. 
As Table 5 depicts, almost majority of the surveyed counsellors (27.4\%) works in schools counting from 101 to 200 students and schools with the number of students of over 500 (19.8\%). The remaining counsellors in schools with 201 to 300 students (16\%) and 301 to 400 students (17.9\%). The fewest $(6.6 \%)$ of the surveyed counsellors represented small schools counting up to 100 students. Such situation results probably from the fact that employment of the counsellor(s) is dependent on the number of students in the given school - approx. 30 of the questionnaires sent were sent back with information that due to the small number of students the counsellor is not employed.

Table 6 presents the number of the counsellors employed in schools.

Table 6

Number of school counsellors employed in the establishment

\begin{tabular}{|c|c|c|}
\hline Number of counsellors & Incidence & $\%$ \\
\hline 1 & 146 & 68.9 \\
\hline 2 & 65 & 30.7 \\
\hline 3 & 1 & 0.4 \\
\hline total & 212 & \\
\hline
\end{tabular}

Source: authoress.

As the above table shows, in the majority of the surveyed schools (68.9\%) only one counsellor is employed, but there is also a tendency to employ two (30.7\%), and even in one case three school counsellors.

\section{Working conditions of school counsellors}

According to the research, all school counsellors have their own office, although sometimes they share it with other specialists, like a psychologist or logopedist.

The surveyed counsellors assessed the standard of the pedagogical office as an average due to lack of equipment, which includes: cabinets for storing documents, telephone, teaching aids, specialist literature, a computer (less frequently), although a few of them bring their own laptop to work or use a computer in the teachers' room or school secretary's office. 
School counsellors often need basic stationery, which is missing, they deal with this problem in various ways: buying it with their own money, raising funds from sponsors, or writing preventive or educational projects.

\section{The duties of a school counsellor}

The duties of the school counsellor, based on the applicable normative acts, should be expressed by the headmaster in writing in the form of an assignment of activities. Most of the respondents (71\%) received such an assignment in writing, the others received it verbally (17 of respondents) or in the form of tasks commissioned every day ( $12 \%$ of respondents). The allocation of activities is the basis of the carried out tasks.

The surveyed school counsellors consider all tasks defined in the Regulation on the rules of providing psychological and pedagogical help in public kindergartens, schools and facilities (Dz.U.2017.1591 [Journal of Laws of 2017, item 1591]) as very important and performed by them very often, as evidenced by the dominant choice of their importance as maximum during the research. At the same time, it turned out that the scope of tasks performed by school counsellors is broader than just tasks resulting from the regulation. All surveyed school counsellors very often undertake additional activities exceeding those of psychological and pedagogical help, and they include:

- contact with external institutions (59.5\%);

- control of students' participation in compulsory education, keeping records of students, the analysis of attendance (42.9\%);

- participation in conferences, trainings and workshops (39.6\%).

Among the frequently performed ones, they enumerated:

- writing reports, preparing statistics and surveys for the use of the governing body, the pedagogical supervision authority and other institutions (33.5\%);

- other activities, such as fulfilling the function of team leaders (educational, in-school teacher training, safety, intra-school evaluation teams), developing an educational and preventive programme, supervising student self-government, being class tutors, supervision of students during breaks (25.5\%). 
Most of the respondents felt that the tasks performed as part of psychological and pedagogical help and additional ones (performed in addition to it) require knowledge and skills in the field of psychology and pedagogy.

During the research, the school counsellors pointed to the decisive factors in the selection of tasks. The factors that mainly determine the choice of tasks are:

- guidelines and recommendations of educational law (97.6\%),

- the expectations of the headmaster and teachers (92.7\%),

- the concept of educational works at a given school (88.2\%),

- students and their needs (86.9\%) as well as current needs of school $(79.6 \%)$.

The most frequently indicated current needs affecting the tasks carried out by teachers are:

- student environment: peer conflicts, aggression among children and adolescents, assistance to students reporting specific problems;

- school environment: preventive actions, absence of teachers, letters coming to school that request giving opinions on students and their family situation;

- family environment: interventions in the environment, participation in meetings of working groups regarding families, interdisciplinary teams, on-going conversations with parents, curators, family assistants, social workers.

The surveyed school counsellors indicated that they cannot manage to accomplish all of the assigned tasks, especially in the field of social assistance, conducting classes with students, pedagogical diagnostics. They perform other tasks just partially, among them they mentioned: prevention of aggression, cooperation with parents, permanent classes, keeping records.

Among the reasons hindering the performance of tasks, they listed:

- excessive amount of duties (93.6\%);

- excessive bureaucracy, which makes it necessary to describe events, actions and interventions (75.3\%);

- lack of time (44.8\%); 
- colleagues' resistance (37.1\%);

- lack of cooperation on the part of parents, their negative attitude to school (34.8\%);

- poor working conditions: improper management, lack of educational aids, poorly equipped schools (21.3\%).

\section{Forms of pedagogical help used in working with students, parents, teachers and class tutors}

Forms of pedagogical assistance are defined in the provisions of educational law - the Education Law Act (Dz.U.2017.59 [Journal of Laws of 2017, item 59]), the Act on the education system (Dz.U.2017.2361 [Journal of Laws of 2017, item 2361], consolidated text) and their interpretations, especially the regulation on the principles of providing and organizing psychological and pedagogical assistance in public kindergartens, schools and facilities.

The forms of assistance that are implemented concern students, their parents as well as teachers and class tutors. The forms of help used in working with students, mentioned by the school counsellors, include: counselling, educational interventions, specialist classes (carried out weekly); psychoeducational classes (several times a month); preventive workshops (several times a year); in addition, didactic and compensatory classes, classes related to the choice of profession and developing talents.

The school counsellors also gave examples of other used forms of pedagogical assistance, i.e.:

- corrective-compensatory and specialist (speech therapy) classes;

- projects;

- sports classes;

- coordinating the work of a socio-therapy centre;

- educational campaigns, social campaigns, preparing students for competitions;

- organization of outings and trips for students.

Parents are another group that uses pedagogical help.

For parents, most often, since every working week, advice and consultations are offered. Several times a month, parents are assisted in organizing 
specialist childcare through appointments in psychological and pedagogical counselling and other specialist clinics. Several times a year, activities are undertaken in the family environment, activities within the interdisciplinary team and life counselling for parents. The school counsellors also indicated additional forms of assistance to parents, including:

- help in looking for a job;

- in solving personal problems, filling out official forms;

- visits, together with parents and students, to specialist doctors (e.g. psychiatrists, neurologists);

- participation in meetings of interdisciplinary teams concerning families.

The last group using pedagogical help are teachers and class tutors.

For teachers and class tutors, weekly support includes: advice and consultation, interventions in the case of negative student behaviour, and counselling in the area of solving educational problems with students and cooperation with parents. The task teams are organized several times a month, and help in analysing, interpreting and developing student documentation. Additional forms of help for teachers and class tutors are also offered including:

- individual conversations;

- solving teacher-student conflicts;

- visiting students' homes together with class tutors;

- educational teams for students;

- observation of students during the lesson.

\section{Local, family and school environment as factors determining the work model of the school counsellor}

The local, family and school environment are the most important factors in the socialization of the young generation. Inherent and inevitable element of the living environment of children and youth, the whole system of institutions serving the organization of collective and cultural life. School, and especially a school counsellor, when planning educational work, must take into account the type and quality of the educational environment in which students live, grow and function. 
The surveyed school counsellors know the local environment in which their schools function. They assessed the intensity of the indicated features, to which they included:

- relationship between the local and global environment;

- accentuating positive values in the environment;

- economic conditions;

- recognizing legal policy as an important element of social life;

- personalization of the local environment;

- and the functioning of institutions supporting the family within the local environment.

In their opinion, all the features listed are at an average or high level. Only few school counsellors indicated the low level. This is probably related to the research area - large and medium-sized cities, where there is extensive industrial and social infrastructure, and various types of outof-school education establishments (cultural centres, community centres). Some of the school counsellors, however, pointed to the low level of such environmental features as: recognition of politics and law as important elements of social life, personalization of the local environment and economic conditions.

Another environment determining the selection of tasks and forms of the counsellor's work is the family environment. The family environment of students with whom the surveyed school counsellors work is diverse. The counsellors' statements show that over $83 \%$ of students are brought up in twoparent families, and over 17\% in single-parent families. Over 19\% of families were assessed by school counsellors as functional. The manifestations of functionality are: interest in children, their development and school situation, as well as offering support and reasonable freedom. Over $20 \%$ of students are brought up in problem families. Among other types of families, school counsellors mentioned:

- families excessively demanding towards children;

- broken and conflict families;

- families neglecting children because of work or focusing on their own problems; 
- reconstructed families;

- families affected by so-called euro-orphanage (parents working abroad).

School counsellors participating in the survey know the problems of the family environment, these problems can be arranged in the following groups:

- addictions in the family (alcoholism, drug addiction - less frequently, gambling);

- inappropriate parental attitudes (overprotection, excessive demands, rejection, inconsistency, negligence);

- cohabitation conflicts (quarrels, aggression, violence);

- family breakdown - separation, divorce;

- bad example of parents (passing negative values, behaviour patterns);

- unemployment;

- no time for the child.

When planning tasks and forms of assistance, school counsellors must take into account the school environment, especially the scope of tasks it carries out. School counsellors pointed to a number of school tasks in educational environment that play an important role in the education of students. Among the most important ones were: knowledge, learning outcomes, adherence to social norms and values resulting from intra-school documentation, taking care of students and caring for their safety, as well as therapeutic, preventive and environmental tasks. The important ones included: activating students by developing self-governance, independence, altruism, creativity as well as innovative and creative activities.

The school counsellors indicated problems among students, which are diagnosed in the school environment. Among them, we can distinguish the following groups:

- aggression (verbal aggression - calling names, swearing, bullying and physical aggression) and violence, including violence with the use of mobile phones and the Internet (cyber violence);

- attendance: truancy, escapes from lessons and/or school, nonperformance of duty of compulsory education;

- conflicts with peers, class and teachers; 
- addictions, mainly nicotine, but also psychoactive drugs, mobile phones, computer, Internet, games;

- low motivation to learn;

- low level of culture and/or personal hygiene of students;

- demoralization.

\section{Individual features important in the profession of school counsellor}

The school counsellor, while performing his/her profession, must have specific competences, which include the knowledge, skills and personal qualities (Urbaniak-Zając, 2016, pp. 71-73). Most of the surveyed counsellors evaluated the following as very good in their case: the ability to learn and improve their own work skills, skilful communication, ethical sensitivity, empathy, openness, mindfulness, pro-social attitudes and a sense of responsibility. As good: their level of psychological and pedagogical knowledge, and the methodology of pedagogical activities supported by experience in its practical use.

The surveyed school counsellors assessed positively their own effectiveness and level of identification with the profession. Most of them assessed their effectiveness as good, rarely very good. Almost all counsellors identify with the profession of school counsellor in a high or good degree, only 3 respondents evaluated their level of identification as average.

\section{Conclusions}

The statistical analysis of the survey results concerning the profession of school counsellor needs to be supplemented with a qualitative analysis. Nevertheless, it allows to formulate the following conclusions:

- the school counsellor is an important element of the psychological and pedagogical support provided in educational institutions;

- one counsellor is usually employed in schools, but there are also institutions with two school counsellors;

- all surveyed counsellors have a master's degree and teaching qualifications, enhanced with various new qualification trainings and trainings improving their skills; 
- the majority of surveyed school counsellors have their own office or share it with another specialist (psychologist or logopedist), but there are problems with the equipment; school counsellors do not have cabinets to store documentation, a telephone, a computer (sometimes); similar deficiencies relate to didactic aids and stationery;

- school counsellors fulfil their duties in accordance with the applicable normative acts and intra-school regulations, they include tasks implemented as part of psychological and pedagogical help and additional tasks,

- the following groups of factors determine the selection of tasks: student environment; school environment, family environment, local environment and current needs of school,

- the following groups of factors do not determine the selection of tasks: voivodship, type of school, the school counsellor's age.

- there are various difficulties in the implementation of tasks, the most common include: lack of time, excessive amount of duties, bureaucratization, colleagues' resistance, lack of cooperation on the part of parents and poor working conditions;

- all surveyed counsellors implement various forms of pedagogical assistance for students, parents and teachers in accordance with the Regulation on the principles of organization and providing psychological and pedagogical assistance in public kindergartens, schools and facilities;

- the surveyed counsellors assess themselves as people with appropriate competences to perform their profession, positively evaluate the effectiveness of their tasks and the level of identification with the profession.

The conducted research has shown that the school counsellor is an important element of psychological and pedagogical help in each of the studied schools. His/her professional tasks are changing along with social and educational changes, and the scope of duties is determined by the school, student's family and local environment in which the school functions. In this profession, professional qualifications and personality predispositions, such 
as creativity, the ability to react quickly, communicativeness, the ability to cope with stress and emotions in difficult situations are extremely important. A crucial element of the quality of the counsellor's work is the school's facilities and equipment, especially having a separate room, telephone, computer and didactic aids to teach classes. A well-prepared counsellor and appropriate conditions guaranteed by the school allow for the fulfilment of the most important duty, which is caring for a child, i.e. a human being.

\section{References}

Bajurska, J. (1995). Praca pedagoga szkolnego $w$ świetle badań. [Interpersonal Relations of a School Counsellor]. Problemy Opiekuńczo-Wychowawcze 3, pp. 22-25. ISSN 0552-218.

Bielecki, R. (2012). Pedagog szkolny: kierunek, oczekiwania, perspektywy. [School Counsellor: Direction, Expectations, Perspectives]. Problemy Opiekuńczo-Wychowawcze 6, pp. 21-28. ISSN 0552-218.

Buhrmester, D., Furman, W., Wittenberg, M.T. i Reis, H.T. (2017). Kwestionariusz Kompetencji Interpersonalnych ICQ-R. Podręcznik [Questionnaire of Interpersonal Competencies ICQ-R. A Manual]. Gdańsk: PTPiP. ISBN 9788365453402.

Dąbek, W.B. (1988). Czynnik warunkujące wykonywanie zadań zawodowych przez nauczycieli-pedagogów szkolnych [Factors Determining the Execution of Professional Tasks by School Counsellors]. Prace Pedagogiczne LXI. Warszawa-Wrocław: PWN.

Dudzikowa, M. (1999). Abberacja optymistyczna "Szkolnego programu wychowania ." An Optimistic Abberation of the "School Education Program"]. Problemy Opiekuńczo-Wychowawcze 7, pp. 3-13. ISSN 0552-218.

Gajewska, G. (2001). Opiekuńczo-wychowawcze możliwości szkoły. [Childcare and Educational Potential of the School]. Problemy Opiekuńczo-Wychowawcze 2, pp. 24-29. ISSN 0552-218.

Juczyński, Z. (2012). Narzędzia pomiaru w promocji i psychologii zdrowia. Podręcznik. [Measurement Instruments in Health Promotion and Health Psychology]. Warszawa: PTP Polskiego Towarzystwa Psychologicznego. ISBN 9788360733431.

Jundziłł, I. (1993). Pedagog szkolny [School Counsellor]. In: W. Pomykało (ed.) Encyklopedia Pedagogiczna [Encyclopedia of Pedagogy] (ed. 1, pp. 91-92). Warszawa: Wyd. Innowacja.

Kwiatkowska, H. (2008). Pedagogika wobec współczesności. Pedeutologia [Pedagogy in the Face of Contemporary World. Pedeutology]. Warszawa: WA i P. ISBN 9788360501276. 
Lewandowska-Kidoń T., Kalinowska-Witek B. (2016) Rola pedagoga szkolnego w szkolnym systemie pomocy psychologiczno-pedagogicznej. [The Role of School Counsellor in the School System of Psychological and Pedagogical Assistance]. Lublin: Wyd. UMCS. ISBN 9788377848586.

Matuszak, A. i Matuszak, Z. (2011). Określenie próby i jej liczności w badaniach pedagogicznych [Definition of the Sample and Its Size in Pedagogical Research]. General and Professional Education 2, ss. 33-39. Accessed 25 ${ }^{\text {th }}$ February 2019 Source: http://genproedu.com/paper/2011-02/full_033-039.pdf

Matyjas, B. (2002). Udział pedagoga szkolnego w pracy opiekuńczo-wychowawczej szkoty. [Participation of a School Counsellor in Childcare and Educational Work at School] Opieka- Wychowanie-Terapia 4, pp. 45-48. ISSN 1230-0861.

Pilch, T. i Bauman, T. (2001). Zasady badań pedagogicznych. Strategie ilościowe i jakościowe. [Principles of Pedagogical Research. Quantitative and Qualitative Strategies]. Warszawa: Wydawnictwo Akademickie Żak. ISBN 8388149695.

Rozporządzenie Ministra Edukacji Narodowej z 9 sierpnia 2017r. w sprawie zasad organizacji i udzielania pomocy psychologiczno-pedagogicznej w publicznych przedszkolach, szkołach i placówkach [Regulation of the Minister of National Education of 9 August 2017 on Organization and Granting Psychological and Pedagogical Help in Public Kindergartens, Schools and Facilities], Dz.U.2017.1591 [Journal of Laws of 2017, item 1591].

Szczepaniak, P. i Strelau, J. i Wiśniewski, K. (1996). Diagnoza stylów rdzenia sobie ze stresem za pomocą polskiej wersji Kwestionariusz CISS Endlera i Parkera. [The Diagnosis of Stress Copying Styles Using the Polish Version of Endler and Parker's CISS Questionnaire]. Przegląd Psychologiczny Polskiego Towarzystwa Psychologicznego 39 (1,2). Gdańsk: GWP, pp. 187-210. ISSN 0048-5675.

Szczurkowska, J. i Mazur, A. (2013). Wokót roli i zadań pedagoga i psychologa w szkole. [On the Role and Tasks of Counsellor and Psychologist at School]. Kielce: Wyd. Pedagogiczne ZNP. ISBN 9788371732775.

Śniatała, H. (2010). Oczekiwania uczniów wobec pedagoga. [Students' Expectations of the School Counsellor]. Problemy Opiekuńczo-Wychowawcze 4, pp. 33-36. ISSN 0552-218.

Urbaniak-Zając, D. (2016). W poszukiwaniu teorii działania profesjonalnego pedagogów. [In Search of the Theory of Professional Activity of School Counsellors]. Kraków: Oficyna Wydawnicza Impuls. ISBN 9788378507734.

Ustawa z 14 grudnia 2016 r. Prawo oświatowe. [Act of 14 December 2016 on the Educational Law]. Dz.U.2017.59. [Journal of Laws of 2017, item 59]. 
Ustawa z 7 września 1991r. o systemie oświaty. [The Act of 7 September 1991 on the Education System] Dz. U.2017. 2198, 2203 i 2361 [Journal of Laws of 2017, 2198, items 2203 and 2361, consolidated text].

Wierzejska, J. (2018). Poczucie podmiotowości pedagogów szkolnych a ich osobowościowe wyznaczniki pracy. [The Sense of Subjectivity of School Counsellors and their Personality Work Determinants]. Lublin: Wyd. UMCS. ISBN 9788322790984.

Wrześniewski, K. (2000). Style i strategie radzenia sobie ze stresem. Problemy pomiaru. [Stress Management Styles and Strategies. Measurement Problems]. In: I. Heszen-Niejodek and Z. Ratajczak (eds), Człowiek w sytuacji stresu. Problemy teoretyczne i metodologiczne [An Individual Under Stress. Theoretical and Methodological Problems] (pp. 51-61). Katowice: Wyd. UŚ. ISBN 8322610084.

Zarządzenie w sprawie nauczyciela pedagoga szkolnego. [Ordinance on School Counsellor] Dz.Urz.MOiW1975.2.112. [Official Journal of the Ministry of National Education of 1975, item 2.112]. 
